\title{
RELATIONSHIP BETWEEN ARABIC LANGUAGE SPEAKING ANXIETY AND MOTIVATION AMONG RELIGIOUS SECONDARY SCHOOL STUDENTS IN MALAYSIA
}

\author{
Zawawi Ismail $^{1 *}$, Nurwaina Rasit ${ }^{2}$, Muhammad Azhar Zailaini ${ }^{3}$, Zaharah Hussin ${ }^{4}$ \\ ${ }^{1 *}$ Associate Prof., University of Malaya, Malaysia; ${ }^{2}$ Lecturer, Institut Pendidikan Guru Kampus Perempuan Melayu, \\ Melaka, Malaysia; ${ }^{3}$ Senior Lecturer, University of Malaya, Malaysia; ${ }^{4}$ Associate Prof., University of Malaya, Malaysia. \\ Email: ${ }^{1 *}$ zawawiismail @um.edu.my, ${ }^{2}$ nurwaina@ipgkpm.edu.my, ${ }^{3}$ azhar@um.edu.my, ${ }^{4}$ zaharah@um.edu.my
}

Article History: Received on $09^{\text {th }}$ January 2020, Revised on $19^{\text {th }}$ April 2020, Published on $21^{\text {st }}$ May 2020

\begin{abstract}
Purpose of the study: This study aimed at identifying the level of Arabic language speaking anxiety and its relationship to motivation among students of religious secondary schools in Malaysia.

Methodology: This quantitative study identifies the anxiety level in speaking Arabic and its relationship with motivation. A survey was done with a selected number of 500 Arabic students out of the total population throughout Malaysia. The survey was done using questionnaires that have been adapted and modified from past studies after completing its validity and reliability process.

Main Findings: The findings indicate that the level of Arabic speaking anxiety among secondary religious school students in Malaysia is moderately high and also shows that students' anxiety in speaking Arabic does not have any significant relationship with their motivation. This finding illustrates that Arabic speaking anxiety is unrelated to student motivation in learning the Arabic Language.

Applications of this study: The study can be useful for Arabic Language teachers. Students with a high anxiety level will feel anxious and avoid taking part in learning activities that will then influence the quality of learning. Hence, speaking anxiety must be tackled separately by the Arabic Language teacher from motivation since there is no significant relationship between the two variables.

Novelty/Originality of this study: This study produced instruments to assess the level of Arabic speaking anxiety. The result of this study is consistent with previous studies, which investigated the level of anxiety in learning a foreign language and speaking anxiety must be tackled separately from motivation because it has no significant relationship with individual students' motivation.
\end{abstract}

Keywords: Relationship, Arabic Language, Speaking Anxiety, Motivation, Religious Secondary School.

\section{INTRODUCTION}

Language anxiety and student motivation are two basic constructs in psychology important in language learning. Past studies on second language learning or even foreign language learning have paid attention to the relationship between language anxiety and motivation. The studies on related issues in affective factors especially were widely debated among researchers in the 1970s (Gardner, 1985; Skehan, 1989). Researchers found that language anxiety is one of the main factors preventing students from mastering the language skills of listening, speaking, reading, and writing (Sila, 2010; Tercan \& Dikilitas, 2015; Horwitz, 2001). MacIntyre and Gardner (1994) and Cheng, Horwitz, and Schallert (1999)stated that studies on language anxiety must be done on specific language skills to identify with specificity and exactness the sources of language anxiety in students. Hence, this study focuses on the level of speaking anxiety and its relationship with motivation. Previous studies have found that language anxiety has a negative relationship with student motivation(Hashimoto, 2002; Khodady \& Khajavy, 2013; Liu \& Huang, 2011; Liu \& Chen, 2015).This shows that the higher the level of language anxiety faced by students, the lower their motivation.

Language anxiety is one aspect most important in teaching and learning in line with the development in the psychology of second language learning in research (Kamarulzaman et al., 2013). It is an effective factor playing an important role in affecting mastery of any language learning. Language anxiety aspect requires attention because of the dominance of its message in creating effective language learning entails focusing on the student's psychological aspect. The term language anxiety appeared when Horwitz, Horwitz, and Cope (1986) described language anxiety as a self- perception, belief, feeling and behaviour related to the classroom language learning process. It involves a negative feeling, fear and pressure experienced by students when learning a language or undertaking activities in the language classroom. Based on this, Horwitz et al. (1986) had developed the language anxiety theory by creating three constructs of language anxiety namely communication apprehension, test anxiety and fear of negative evaluation. Language anxiety theory plays a key role in language research and such theories have become very influential in this field. Horwitz et al. (1986) defined the construct communication apprehension as a feeling of shyness, fear and anxiety, difficulty in communicating with others and understanding others. The second construct or test anxiety is anxiety elated to academic evaluation whereby the student fears facing failure in tests. It represents an uncomfortable situation and occurs either consciously or not within the awareness of the student. The third construct (fear of negative evaluation) consists of anxiety related to others' evaluation and that the students' perceptions will be evaluated as negative in foreign language learning. The students are 
afraid of being evaluated by teachers or their friends and can make people avoid discussing and socializing with others. They also think that they are unable to achieve effective social communication.

Because of wide research in this field, Horwitz et al. (1986) had created an instrument called the Foreign Language Classroom Anxiety Scales (FLCAS) to measure the level of student language anxiety. This instrument has been widely used among researchers of several languages and is used in most countries all over the world as a big part of language research projects (Horwitz, 2001; Woodrow, 2006). Many researchers have adopted and adapted this instrument to their own research needs (Muhammad Sabri, 2012). Items in the FLCAS were created based on three constructs of language anxiety namely communication anxiety, test anxiety and negative evaluation anxiety. All items in the instrument were built based on identifying the anxiety level related to language learning and whether the anxiety level influenced student academic achievement. Because of the wide research carried out in this field, many other instruments have been developed to measure student language anxiety in various fields of language and language skills (Cheng, 2001).

\section{LITERATUR REVIEW}

Researchers have defined language anxiety in multiple ways. Spielberger (1983) defined anxiety by relating it to a psychological symptom or a feeling of subjective tension, worry, fear and discomfort associated with the nervous system in situations of foreign language learning. MacIntyre and Gardner (1994) defined language anxiety as a feeling of tension and fear of speaking, listening or emotional negative reaction arising when learning and using a foreign language. They depicted the students having language anxiety as individuals experiencing discomfort, who often withdraw from involving in voluntary classroom activities, who feel pressured not to make mistakes and are unprepared to learn a language. Dornyei (2009) emphasized that anxiety is among the five major factors for individuals learning languages apart from language ability, motivation, learning style and learning strategy.

Wan Zakaria et al. (2007) stated that anxiety appears when an individual undergoes a negative or dangerous situation. Language anxiety among students depends on their experience in implementing language learning in an applied cognitive way. If anxiety disrupts cognitive function, students will be unable to master what is learned (Von Worde, 2003). In an indirect way, they will increase language anxiety among themselves. In the context of this study, anxiety feeling is an analysis of the anxiety or tension experienced by students in secondary religious schools in Malaysia. It encompasses the combination of various related feelings such as fear, apprehension, tension and worry caused by learning the Arabic language specifically in speaking skill.

The speaking skill aspect plays a very important role in learning the language. Bailey (2005) explained that speaking skill is a skill hard to learn, unlike the other language skills. In the context of language anxiety, speaking skill has been identified as a problem most dominant over students in learning a foreign language as compared with other skills such as listening, writing and reading (Gregersen \& Horwitz, 2002; Horwitz et al., 1986; Humphries, 2011; MacIntyre \& Gardner, 1994; Sila, 2010). Tanveer (2007) stated that the most critical challenge for most students in foreign language learning is speaking skill. Mak (2011) and Liu (2006) noted that anxiety has a negative influence on the performance and capability of students to process information in language learning. Students need to access quickly the relevant existing knowledge in themselves for producing the right language to communicate in a short time (Shabani, 2015). Because of this, students were found very anxious and pressured when asked to speak in class (Von Worde, 2003).

In general, the objective of Arabic language teaching and learning in Malaysia is to enable the students to master the four language skills namely listening, speaking, reading and writing. Although the Ministry of Education has made many initiatives, many studies have proven that students are still weak in mastering the Arabic language, especially in mastering speaking. Mohamad (2009) found that student use of Arabic in speaking is low because of internal problems faced such as fear and embarrassment at making mistakes, low self-esteem, lack of enthusiasm and fear of being ridiculed. A study by Yusri et al. (2010) also found that student attitude of being easily disappointed and embarrassed at weaknesses made them lose self -confidence and thus they felt low self -esteem to speak in the Arabic language. Aladdin (2012) stated that among the major problems faced by students is when speaking in the Arabic language; students were often unable to articulate words or form proper grammatical sentences as intended for the hearer. The students feel disappointed, lacking in confidence, afraid and embarrassed if they make mistakes when speaking in the Arabic language.

Studies on students in higher learning institutions also found the students weak in Arabic language speaking skill. Arshad and Abu Bakar (2012) showed that a majority of students in the Islamic education field have not mastered speaking skill despite being exposed widely to the Arabic language since secondary school. Daud and Abdul Pisal (2014) showed that difficulty in the Arabic language had hindered student capabilities in activities requiring speaking skills. Students faced more problems completing individual assignments because they have to do them alone, shyness, lack of confidence and lack of interest. Besides that Arshad (2013) had shown that the majority of students who sit for the APT Skills Test failed to passband 6 in the Maharat al-Kalam (speaking skills section). It can be concluded that the weaknesses in these students are a manifestation of the Arabic language speaking anxiety they faced. Although many previous studies had detailed the problems with speaking skills among students, no specific study has been done to emphasize language anxiety as one of the sources of weakness in Arabic language mastery. Hence, this study is aimed at 
investigating the language anxiety level and its relationship with motivation among religious secondary school students in Malaysia.

\section{Motivation}

Motivation is defined as the desire to create the action as well as maintain the intention to achieve the desired outcome (Ames \& Ames, 1989). Siraj, Ishak and Tunku Mokhtar (1996) explained that motivation is the activator of individual need and desire to succeed or achieve an aim. In the language learning context, Gardner (1985) emphasized that motivation is the main element with language ability in determining success in the language classroom. A strong and positive motivation for learning in students is important for achieving language learning. Students with high motivation find it easier to master a language (Nik Yusoff, Mahamod, \& Ab. Ghani, 2008). Motivation is also a factor giving energy and momentum to a student to act until learning becomes more active and effective (Mat Teh \& Embi,2010). According to Oxford and Shearin (1994), motivation shows activation and personal involvement in foreign or second language learning. Unmotivated students will be unable to develop their language skills to fulfil their potential. Gardner (1985) was a pioneer who suggested the theory of motivation and saw motivation as a combination of effort and desire to achieve language learning goals. He carried out much research on language learning motivation within the socioeducational framework (Gardner, 1985; Gardner \& Lambert, 1972).In this model, Gardner (1985) focused on the motivation aspect through two main orientations in language learning, namely integrative orientation and instrumental orientation. Integrative orientation refers to individual reasons for learning a second language aimed at interacting with, getting closer or understanding the second language community. It represents the desire or needs to be like another language community and having a relationship with that community. The learners made efforts to interact and communicate with the language speaker, in fact, to be accepted as a member of that speaking community.

Instrumental orientation, on the other hand, emphasizes the individual's need for social recognition or economic benefit through knowing another language such as success in examinations, continuing education overseas or getting employment. The distinction between integrative and instrumental motivation has inspired many studies on motivation in language learning. Based on this principle, Gardner (1985) had developed an instrument called the Attitude Motivation Test Battery (AMTB) with variables namely integrative and instrumental orientation, attitude, learning situation, motivation and language anxiety. Nevertheless, in this study, we will only focus on the aspects of integrative and instrumental orientation and motivation to achieve the research objectives. The relationship between motivation and language anxiety has been explored by many researchers. Most researchers have found that language anxiety has a negative relationship with motivation (Gardneret al., 1987; Hashimoto, 2002; Huang, 2005; Liu, 2011). This shows that the higher the level of anxiety experienced by the students, the lower their motivation to acquire a foreign language. This also shows that anxiety has a negative relationship and is a contributing factor to low motivation among students. Hence, this study aims at identifying the level of Arabic speaking anxiety among Arabic language students in secondary religious schools in Malaysia and its relationship with motivation.

\section{METHODOLOGY}

This study is using a survey research design to identify the Arabic speaking anxiety level and its relationship with motivation among religious secondary school students in Malaysia. This study is a descriptive study using survey design and using quantitative data analysis method. The survey methods can collect data directly from respondents and generalizations can be made to the population in research.

The population of this study is Arabic students in SMKA and SABK throughout Malaysia. The total population of the study was 107,621 persons, the total number of Arabic students in 55 SMKAs and 143 SABKs throughout Malaysia (Islamic Education Division, 2018). Out of the total population, 500 people were to be selected as the study sample. All of these samples were taken in randomly selected school students based on 5 zones. Each zone represented 100 samples. In this study, researchers used a random sampling method to obtain population-related data. This type of sample is best used for studies based on zone, state, division and district or sample selection based on several categories. Therefore, the designation of 500 respondents as the study sample was made based on the sample size determination table. According to Krejcie \& Morgan (1970), the sum of 500 samples for this study is sufficient to represent the existing population.

Descriptive statistics analysis and inference statistics were used in this study. The collected data obtained in this study were coded and quantitatively analysed using SPSS version 23. This descriptive analysis involves all the constructs involved in the study. The descriptive analysis used involves percentage, mean and standard deviation while statistical analysis of inference is carried out to find solutions to the research questions that have been developed. This statistic is used to describe the correlation between the two variables: Arabic speaking anxiety and motivation.

The instrument used for measuring the constructs of speaking anxiety and motivation is from the survey questionnaires adapted and modified and combined with instruments from past studies by namely the Foreign Language Classroom Anxiety Scale (FLCAS) by Horwitz et al. (1986) and the Foreign Language Speaking Anxiety Scale (FLSAS) by Balemir (2009) and the Attitude/Motivation Test Battery (AMTB) by Gardner (1985). This instrument has been submitted to a panel of experts in the relevant field for validation. Expert reviews are necessary to ensure the accuracy of the construction and the clarity of the content. All of these items were also tested for validity and reliability through Alpha Cronbach and EFA assessments. The purpose of the exploratory factor analysis was to evaluate the reliability, 
item specificity and internal consistency of the study. Cronbach's alpha for each construct also showed a good value of 0.855 for anxiety speaking skill and 0.971 for student motivation. Through the analysis of these exploratory factors, only items with high correlation will be retained in the questionnaire.

Therefore, only 12 items under the language anxiety construct and 14 items under the construct student motivation were chosen for this study. The questionnaire is based on a five-point Likert scale. The researcher used descriptive statistics to evaluate the mean, standard deviation and frequency and inferential statistics for the Pearson correlation test.

\section{RESULTS/FINDINGS}

The following Table 1 displays the frequency, percentage and mean, standard deviation and interpretation of the mean for anxiety in speaking in Arabic.

Table 1: Frequency, percentage and mean, standard deviation and interpretation of the mean for anxiety in Arabic speaking

\begin{tabular}{|c|c|c|c|c|c|c|c|c|}
\hline Aspect & SD & Disagree & Neutral & Agree & $\begin{array}{l}\text { Strongly } \\
\text { Agree }\end{array}$ & Mean & $S D$ & Interpretation \\
\hline $\begin{array}{l}\text { Facing oral test in the } \\
\text { Arabic language }\end{array}$ & $\begin{array}{c}12 \\
(2.4 \%)\end{array}$ & $\begin{array}{c}46 \\
(11.6 \%)\end{array}$ & $\begin{array}{c}109 \\
(33.4 \%)\end{array}$ & $\begin{array}{c}212 \\
(75.8 \%)\end{array}$ & $\begin{array}{c}121 \\
(24.2 \%)\end{array}$ & 3.77 & 0.99 & Moderately high \\
\hline $\begin{array}{l}\text { Oral Arabic test is } \\
\text { carried out }\end{array}$ & $\begin{array}{c}14 \\
(2.8 \%)\end{array}$ & $\begin{array}{c}57 \\
(11.4 \%)\end{array}$ & $\begin{array}{c}108 \\
(21.6 \%)\end{array}$ & $\begin{array}{c}220 \\
(44 \%)\end{array}$ & $\begin{array}{c}101 \\
(20.2 \%)\end{array}$ & 3.67 & 1.01 & Moderately high \\
\hline $\begin{array}{l}\text { Other students speak } \\
\text { better in the Arabic } \\
\text { language }\end{array}$ & $\begin{array}{c}8 \\
(1.6 \%)\end{array}$ & $\begin{array}{c}49 \\
(9.85)\end{array}$ & $\begin{array}{c}131 \\
(26.2 \%)\end{array}$ & $\begin{array}{c}225 \\
(45 \%)\end{array}$ & $\begin{array}{c}87 \\
(17.4 \%)\end{array}$ & 3.67 & 0.92 & Moderately high \\
\hline $\begin{array}{l}\text { Not confident speaking } \\
\text { in an Arabic language } \\
\text { class }\end{array}$ & $\begin{array}{c}5 \\
(1 \%) \\
\end{array}$ & $\begin{array}{c}60 \\
(12 \%) \\
\end{array}$ & $\begin{array}{c}124 \\
(24.8 \%)\end{array}$ & $\begin{array}{c}241 \\
(48.2 \%)\end{array}$ & $\begin{array}{c}70 \\
(14 \%) \\
\end{array}$ & 3.62 & 0.90 & Moderately high \\
\hline $\begin{array}{l}\text { Speaking without } \\
\text { preparation in an Arabic } \\
\text { language class }\end{array}$ & $\begin{array}{c}22 \\
(4.4 \%)\end{array}$ & $\begin{array}{c}62 \\
(12.4 \%)\end{array}$ & $\begin{array}{c}145 \\
(29 \%)\end{array}$ & $\begin{array}{c}198 \\
(39.6 \%)\end{array}$ & $\begin{array}{c}73 \\
(14.6 \%)\end{array}$ & 3.48 & 1.02 & Moderately high \\
\hline $\begin{array}{l}\text { Knowing that I will be } \\
\text { evaluated in Arabic } \\
\text { language learning }\end{array}$ & $\begin{array}{c}22 \\
(4.4 \%)\end{array}$ & $\begin{array}{c}75 \\
(15 \%) \\
\end{array}$ & $\begin{array}{c}144 \\
(28.8 \%)\end{array}$ & $\begin{array}{c}212 \\
(42.4 \%)\end{array}$ & $\begin{array}{c}47 \\
(9.4 \%)\end{array}$ & 3.37 & 0.99 & Moderately high \\
\hline $\begin{array}{l}\text { Giving the wrong } \\
\text { answer in an Arabic } \\
\text { language class }\end{array}$ & $\begin{array}{c}16 \\
(3.2 \%)\end{array}$ & $\begin{array}{c}76 \\
(15.2 \%)\end{array}$ & $\begin{array}{c}164 \\
(32.8 \%)\end{array}$ & $\begin{array}{c}195 \\
(39 \%)\end{array}$ & $\begin{array}{c}49 \\
(9.8 \%)\end{array}$ & 3.37 & 0.96 & Moderately high \\
\hline $\begin{array}{l}\text { Name called in an } \\
\text { Arabic language class }\end{array}$ & $\begin{array}{c}46 \\
(9.2 \%)\end{array}$ & $\begin{array}{c}82 \\
(16.4 \%)\end{array}$ & $\begin{array}{c}153 \\
(30.6 \%)\end{array}$ & $\begin{array}{c}155 \\
(31 \%)\end{array}$ & $\begin{array}{c}64 \\
(12.8 \%)\end{array}$ & 3.22 & 1.14 & Moderately high \\
\hline $\begin{array}{l}\text { Teacher corrects my } \\
\text { mistakes when I speak } \\
\text { in the Arabic language }\end{array}$ & $\begin{array}{c}59 \\
(11.8 \%)\end{array}$ & $\begin{array}{c}105 \\
(21 \%) \\
\end{array}$ & $\begin{array}{c}125 \\
(25 \%)\end{array}$ & $\begin{array}{c}169 \\
(33.8 \%)\end{array}$ & $\begin{array}{c}42 \\
(8.4 \%) \\
\end{array}$ & 3.06 & 1.16 & Moderately high \\
\hline $\begin{array}{l}\text { The teacher asks another } \\
\text { student to correct my } \\
\text { mistake during Arabic } \\
\text { speaking }\end{array}$ & $\begin{array}{c}43 \\
(8.6 \%)\end{array}$ & $\begin{array}{c}116 \\
(23.2 \%)\end{array}$ & $\begin{array}{c}156 \\
(31.2 \%)\end{array}$ & $\begin{array}{c}149 \\
(29.8 \%)\end{array}$ & $\begin{array}{c}36 \\
(7.2 \%)\end{array}$ & 3.04 & 1.07 & Moderately high \\
\hline $\begin{array}{l}\text { Other students laugh at } \\
\text { me when I speak Arabic }\end{array}$ & $\begin{array}{c}65 \\
(13 \%) \\
\end{array}$ & $\begin{array}{c}97 \\
(19.4 \%)\end{array}$ & $\begin{array}{c}148 \\
(29.6 \%)\end{array}$ & $\begin{array}{c}140 \\
(28 \%)\end{array}$ & $\begin{array}{c}50 \\
(10 \%)\end{array}$ & 3.03 & 1.18 & Moderately high \\
\hline $\begin{array}{l}\text { Following } \\
\text { speaking class because } \\
\text { of fear of being } \\
\text { corrected by the teacher }\end{array}$ & $\begin{array}{c}70 \\
(14 \%)\end{array}$ & $\begin{array}{c}124 \\
(24.8 \%)\end{array}$ & $\begin{array}{c}162 \\
(32.4 \%)\end{array}$ & $\begin{array}{c}114 \\
(22.8 \%)\end{array}$ & $\begin{array}{c}30 \\
(6 \%)\end{array}$ & 2.82 & 1.11 & Moderately low \\
\hline Overall Mean & & & & & & 3.29 & 0.57 & Moderately high \\
\hline
\end{tabular}

The first question in this study is aimed at identifying the level of Arabic language speaking anxiety in students. Table 1 shows the distribution of frequency, percentage, mean, standard deviation and mean interpretation for Arabic speaking anxiety level for Arabic language students. The findings show that on the whole students' experience speaking anxiety at a moderately high level with a Mean $=3.29(S D=0.57)$. All items obtained a mean value at a moderately high level except for one item at a moderately low level. The highest mean was $3.77(S D=0.99)$ for the aspect of anxiety in facing oral Arabic language test. Meanwhile, the lowest mean obtained was $2.82(S D=1.11)$ for the item anxiety in following the Arabic language speaking class because of fear of being corrected by the teacher. 
The aspect of anxiety when facing oral Arabic tests attained the highest mean among students $(M=3.77)$ and this shows that students often undergo speaking anxiety when facing oral Arabic tests. It is also congruent with findings by Mazouzi (2013) who studied student perception of language anxiety in oral English language tests. All the respondents agreed that they experienced anxiety when facing oral tests. Zhang and Liu (2013) also showed that students faced anxiety during English oral tests and this affected their test performance. Horwitz et al. (1986) and Young (1991) also clarified that anxiety in oral tests experienced by students of the second language was very high in speaking.

Student anxiety and motivation are two basic constructs in educational psychology. This study has shown that no relationship exists between Arabic speaking anxiety and student motivation. The analysis of the relationship between the two variables is given in Table 2 .

Table 2: Correlation between speaking anxiety and motivation

\begin{tabular}{llll}
\hline Correlations & & & \\
\hline \multirow{2}{*}{ Speaking } & \multicolumn{1}{l}{ Searson Correlation } & 1 & .015 \\
\cline { 2 - 4 } & Sig. (2-tailed) & & .743 \\
\cline { 2 - 4 } & $\mathrm{N}$ & 500 & 500 \\
\hline Motivation & Pearson Correlation & .015 & 1 \\
\cline { 2 - 4 } & Sig. (2-tailed) & .743 & \\
\cline { 2 - 4 } & $\mathrm{N}$ & 500 & 500 \\
\hline
\end{tabular}

Table 2 represents the results of an analysis of the correlation between speaking anxiety and student motivation ( $r=.015$, $p>.05)$ at the 0.01 level of significance. The relationship shows that Arabic speaking anxiety does not have a significant relationship or association with motivation. Findings of the Pearson correlation test show a very weak $(r=.015)$ correlation between the two variables. In other words, the findings of this study illustrate that speaking anxiety is unrelated to student motivation. Hence, speaking anxiety must be tackled separately from motivation because it has no significant relationship with individual student motivation. This study supports the findings of Yusri et al. (2010) that no significant relationship existed between intrinsic and extrinsic motivation and with test anxiety in the context of student Arabic speaking skills. The findings of this study, however, contradict several findings of studies showing that a negative relationship existed between speaking anxiety and student motivation (Aida, 1994; Liu \& Huang, 2011). Hence, to create an effective teaching and learning environment, teachers must be aware of and emphasize the Arabic language anxiety experienced by students and give the requisite motivation to them. Efforts must be made to ensure that students can overcome their Arabic speaking anxiety effectively and subsequently enhance their Arabic speaking proficiency.

\section{DISCUSSION / ANALYSIS}

Findings of this study support that of Rasmodjo (2011) who found that the majority of students undergo anxiety at a moderately high level before sitting oral tests and when facing questions or ideas new to them during the oral test. McCroskey (1984) found that students having high anxiety level in speaking will try to avoid taking part in activities involving spontaneous speech. The students will feel anxious because they are unable to organize and present their speech properly with confidence and this makes them afraid and embarrassed. They have a negative perception toward response or feedback from listeners or their peers regarding their choice of vocabulary and weak organization of ideas when speaking. Zheng (2008) explained that anxiety will influence speed and exactness in speaking and can affect the quality of communication output.

Many factors contribute to anxiety in Arabic speaking among students. Among them is lack of a supportive culture and environment for students to speak in the Arabic language. The students feel more comfortable practicing their mother tongue than the second language learned such as Arabic. Many studies have been done on factors related to problems of mastering Arabic language skills and these studies came to a similar conclusion: a weak learning environment. Musilehat (2012) found that less emphasis on applying Arabic speaking at school level hindered student ability to speak well in Arabic. The Arabic language was used mainly during the teaching process while the environment of Arabic-speaking itself was important for creating active learning among students. It would also enhance student social skills especially in mastering the Arabic language.

The situation worsens when some teachers were found not to use the Arabic language in the classroom teaching and learning process (Nik Yusoff et al., 2006). If the teachers always implement Arabic language speaking this will directly give a positive effect on students. (Yusri et al., 2010). Right now, although the Arabic language has been introduced at the school level, it still is unable to shape student attitude and interest to deepen and enhance their mastery of the Arabic language. This is because of the students' perception that learning the Arabic language is not important and that learning is merely to gain reward in examinations. Hence, students restrict their Arabic language learning to the extent of 
obtaining the targeted grades (Yusri et al., 2010). Hence it is necessary to make an effort to change the students' attitude and perception toward Arabic in the future beginning at the school level. Students need to impress upon themselves that the Arabic language is easy to learn and understand. Nik Yusoff et al. (2006) clarified that in order to reduce speaking anxiety in students, teachers can implement group projects because students with high or low levels of anxiety will have the same opportunity to be involved and cooperate in the group activities. The students will be more enthusiastic when involved in group oral activities (Young, 1991) because the environment encourages usage of the language learned. Nagahashi (2007) stated that cooperative learning techniques can reduce anxiety and increase students' opportunities to speak.

In order to lower anxiety in speaking Arabic among students, teachers play a role in creating a more peaceful and calm classroom environment (Akkakoson, 2016). An effective teacher is one who can build a good relationship with the student from an emotional viewpoint. A friendly teacher-student relationship will make the student more comfortable and motivated to be involved in-class activities. It will also be able to support student emotional development and build a positive attitude in achieving academic outcomes. Besides that, teachers also need to give continuous motivation to the students to enhance their belief in their capability in speaking Arabic. Daud and Abdul Pisal (2014) explained that highly motivated students will have more confidence to speak in the Arabic language because they can handle any problem when speaking with various individual ways. High confidence can help students to present their message with fluency. Subasi (2010) also clarified that when the students have high confidence in their capability to do something, they will not experience anxiety. Teachers need to guide students using effective and systematic communication strategies always; in this way, students will be more motivated, brave, and confident to continue conversing in the Arabic language.

\section{CONCLUSION}

This study found that, on the whole, the level of Arabic speaking anxiety among secondary religious school students in Malaysia is at a moderately high level. Students were found to be anxious and fearful speaking in the Arabic language especially when facing oral tests because they were unable to organize and present their speech correctly and confidently. Findings of this study also show that Arabic speaking anxiety faced by students does not have a significant relationship with motivation. This finding illustrates that Arabic speaking anxiety is unrelated to student motivation. Hence, speaking anxiety must be tackled separately from motivation since there is no significant relationship between the two variables. The teacher's role in creating a friendly, cooperative and enthusiastic Arabic language learning environment is important during the classroom teaching and learning process. This will help to reduce the student anxiety level in learning and mastering the Arabic language in school. Teachers also play a role and need to always be aware of the psychological needs and affective development of students to guarantee the effectiveness of Arabic language teaching and learning besides giving continuous motivation to students.

\section{LIMITATION AND STUDY FORWARD}

This study only focuses on Arabic speaking anxiety and its relationship with student motivation. The future scope of the research could be done to identify the other Arabic language skills (listening, writing and reading) and their relationship with motivation. In addition, this study could also be expanded to other students who learn the Arabic Language as a foreign language.

\section{ACKNOWLEDGEMENT}

We would like to thank the Faculty of Education, University of Malaya and Ministry of Education Malaysia for the support and providing a great facility to conduct the research.

\section{AUTHORS CONTRIBUTION}

Nurwaina was responsible for designing the instrument, data collection, and literature review. Zawawi Ismail was tasked with the data analysis, writing the methodology section, and preparing the final version review. Azhar Zailani contributed by adding information, writing the suggestions, and reviewing the paper. Lastly, Zaharah Hussin was in charge of the discussion and conclusion sections.

\section{REFERENCES}

1. Aida, Y. (1994). Examination of Horwitz, Horwitz, and Copes Construct of Foreign Language Anxiety: The case of students of Japanese. Modern Language Journal, 78(2), 155-168. https://doi.org/10.1111/j.15404781.1994.tb02026.x

2. Akkakoson, S. (2016). Speaking anxiety in English conversation classrooms among Thai students. Malaysian Journal of Learning and Instruction, 13, 63 - 82. https://doi.org/10.32890/mjli2016.13.1.4

3. Aladdin, A. (2012). Analisis penggunaan strategi komunikasi dalam komunikasi lisan Bahasa Arab. GEMA Online ${ }^{\circledR}$ Journal of Language Studies, 12(2), 645-666.

4. Ames, R., Ames C., Eds. (1989). Goals and cognitions. Research on Motivation in Education, Vol. 3, 1-10. New York, NY: Academic Press. 
5. Arshad, M. (2013). Penggunaan Strategi Pembelajaran Kemahiran Bertutur Bahasa Arab dalam kalangan pelajar Melayu di Pusat Asasi UIA. In Proceedings of ILCC 2013 International Language, International Language for Communication Conference, (pp. 319-330).

6. Arshad, M. \& Abu Bakar, K. (2012). Penggunaan strategi pembelajaran kemahiran bertutur Bahasa Arab: Kajian di Pusat Asasi UIAM. In M.S. Hamzah, K. Osman, M. Hussain, S. Zailani @ Hj. Ahmad, S. A. Ghani, H. Zainal, \& Z. Ismail (Eds.), Persidangan Kebangsaan Pengajaran Dan Pembelajaran Bahasa Arab 2012 (pp. 139-155). Unit Bahasa Arab, Fakulti Pengajian Islam, Universiti Kebangsaan Malaysia..

7. Bailey, K.M. (2005). Practical English Language teaching: Speaking. New York: McGraw-Hill.

8. Balemir, S. H. (2009). The sources of foreign language speaking anxiety and the relationship between proficiency level and the degree of foreign language speaking anxiety. (Master's thesis, Bilkent University, Turkey).

9. Cheng, Y.S. (2001). Learners' beliefs and Second Language Anxiety. Concentric: Studies in English Literature and Linguistics, 27(2), 209-223.

10. Cheng, Y.S., Horwitz, E. K., \& Schallert, D. L. (1999). Language anxiety: Differentiating writing and speaking components. Language Learning, 49(3), 417-44. https://doi.org/10.1111/0023-8333.00095

11. Daud, N. \& Abdul Pisal, N. (2014). Permasalahan pertuturan dalam Bahasa Arab Sebagai Bahasa Kedua. GEMA Online TM Journal of Language Studies, 14(1), 117-133. https://doi.org/10.17576/GEMA-2014-1401$\underline{08}$

12. Dornyei, Z. (2009). Individual differences: Interplay of learner characteristics and learning environment. Language Learning, 59.(Suppl. 1), 230-248. https://doi.org/10.1111/j.1467-9922.2009.00542.x

13. Gardner, R. C. (1985). Social psychology and Second Language Learning: The role of attitudes and motivation. London, UK: Edward Arnold.

14. Gardner, R. C., \& Lambert, W. E. (1972). Attitudes and motivation in Second Language Learning. Rowley, MA: Newbury House.

15. Gardner, R. C., Lalonde, R. N., Moorcroft, R., \& Evers, F. T. (1987). Second language attrition: The role of motivation and use. Journal of Language and Social Psychology,6, 29-47. https://doi.org/10.1177/0261927X8700600102

16. Gregersen, T., \& Horwitz, E. K. (2002). Language learning and perfectionism: Anxious and non-anxious. The Modern Language Journal, 86, 562-570. https://doi.org/10.1111/1540-4781.00161

17. Hashimoto, Y. (2002). Motivation and willingness to communicate as predictors of reported L2 use: The Japanese ESL context. Second Language Studies, 20, 29-70.

18. Horwitz, E. K. (2001). Language anxiety and achievement. Annual Review of Applied Linguistics, 21(1), 112126. https://doi.org/10.1017/S0267190501000071

19. Horwitz, E.K., Horwitz, M.B., \& Cope, J. (1986). Foreign language classroom anxiety. The Modern Language Journal, 70, 125-132. https://doi.org/10.2307/327317

20. Huang, H.W. (2005). The relationship between learning motivation and speaking anxiety among EFL nonEnglish major freshmen in Taiwan. (MA thesis, Chaoyang University of Technology, Taiwan).

21. Humphries, R. (2011). Language anxiety in international students. Griffith Working Papers in Pragmatics and Intercultural Communication, 4(1/2), 65-77.

22. Kamarulzaman, M.H., Ibrahim, N., Md Yunus, M., \& Mohd Ishak, N. (2013). Language anxiety among gifted learners in Malaysia. English Language Teaching, 6(3), 20-29. https://doi.org/10.5539/elt.v6n3p20

23. Khodady, E., \& Khajavy, G.H. (2013). Exploring the role of anxiety and motivation in foreign language achievement: A Structural Equation Modelling approach. Porta Linguarum, 20, 269-286.

24. Krejcie, R.V., \& Morgan, D.W., (1970). Determining Sample Size for Research Activities. Educational and Psychological Measurement. https://doi.org/10.1177/001316447003000308

25. Liu, H. J. (2011). Exploring foreign language anxiety and motivation among young adolescents in Taiwan. Tamsui Oxford Journal of Arts, 11, 75-92. https://doi.org/10.1155/2011/493167

26. Liu, H. J., \& Chen, C. W. (2015). A comparative study of foreign language anxiety and motivation of academic- and vocational-track high school students. English Language Teaching, 8(3), $193-204$. https://doi.org/10.5539/elt.v8n3p193

27. Liu, M. L. (2006). Anxiety in Chinese EFL students at different proficiency levels. System, 34, $301-316$. https://doi.org/10.1016/j.system.2006.04.004

28. Liu, M., \& Huang, W.(2011). Exploration of foreign language anxiety and English learning motivation. Education Research International, 1-8. https://doi.org/10.1155/2011/493167

29. MacIntyre, P.D., \& Gardner, R.C. (1994). The subtle effects of language anxiety on cognitive processing in the second language. Language Learning, 44(2), 283- 305. https://doi.org/10.1111/j.14671770.1989.tb00423.x

30. Mak, B. (2011). An exploration of speaking in class anxiety with Chinese ESL learners. System,39, $202-214$. https://doi.org/10.1016/j.system.2011.04.002

31. Mat Teh, K.S., \& Embi, M.A. (2010). Strategi pembelajaran bahasa. Kuala Lumpur, Malaysia: Universiti Malaya. 
32. Mazouzi, S. (2013). Analysis of some factors affecting learners' oral performance. A Case Study: 3rd Year Pupils of Menaa's Middle Schools. (MA dissertation, Department of Foreign Languages, English Division, Faculty of Letters and Languages, Mohamed Khider University of Biskra, People's Democratic Republic of Algeria).

33. McCroskey, J. C. (1984). The communication apprehension perspective. InJ.A. Daly \& J.C. McCroskey (Eds.), Avoiding communication: Shyness, reticence, and communication apprehension. Beverly Hills, CA: Sage.

34. Mohamad, A.H. (2009). Tahap komunikasi dalam Bahasa Arab dalam kalangan pelajar Sarjana Muda Bahasa Arab di IPTA Malaysia. JIAE: Journal of Islamic and Arabic Education, 1(1), 1-14.

35. Muhammad Sabri, R. (2012). Second language learning anxiety among Malay learners of English. (Masters thesis, Universiti Malaya, Kuala Lumpur).

36. Musilehat, N.S. (2012). The effects of Arabic teaching methodology at SMAASZA on the acquisition of speaking skill. (Unpublished MA thesis, International Islamic University Malaysia).

37. Nagahashi, T. L. (2007). Techniques for reducing foreign language anxiety: Results of asuccessful intervention study. Annual Research Report on General Education, Akita University,9, 53-60.

38. Nik Yusoff, N.M.R., Ab. Ghani, K. \& Ismail, Z. (2006). Tahap kemahiran kefahaman mendengar di kalangan pelajar Sekolah Menengah Agama Negeri. Jurnal Teknologi,45(E), 83-98. https://doi.org/10.11113/jt.v45.349

39. Nik Yusoff, N.M.R., Mahamod, Z., \& Ab. Ghani, K. (2008). Motivasi pembelajaran kemahiran mendengar Bahasa Arab dan hubungannya dengan pencapaian pelajar. Jurnal Pendidikan, 33, 3-8.

40. Oxford. R., \& Shearin, J. (1994). Language learning motivation: Expanding the theoretical framework. The Modern Language Journal,78(1), 12-28.

41. Rasmodjo, V. R. (2011). Anxiety in oral performance test: A case study of Indonesian learners. Indonesian Journal of English Language Teaching, 7(2), 65-68.

42. Shabani, M.B. (2015). On the relationship between Foreign Language Anxiety and Language Learning Strategies among Iranian EFL Learners. International Journal of Educational Investigations, Vol.2 (2), 9-23.

43. Sila, A.Y., (2010). Young adolescent students' foreign language anxiety in relation to language skills at different levels. The Journal of International Social Research,3(11), 83-91.

44. Siraj, S., Ishak, Z. \& Tunku Mokhtar, T.M. (1996). Motivasi dalam pendidikan. Kuala Lumpur, Malaysia: Utusan.

45. Skehan, P. (1989). Individual differences in second language learning. London, UK: Edward Arnold.

46. Spielberger, C. D. (1983). Manual for The State-trait Anxiety Inventory. Palo Alto, CA: Consulting Psychologists Press. https://doi.org/10.1037/t06496-000

47. Subaşi, G. (2010). What are the main sources of Turkish EFL students' anxiety in oral practice? Turkish Online Journal of Qualitative Inquiry, 1(2), 29-49.

48. Tanveer, Muhammad. (2007). Investigation of the factors that cause language anxiety for ESL/EFL learners in learning speaking skills and the influence it casts on communication in the target language. (Unpublished thesis, Faculty of Education, University of Glasgow).

49. Tercan, G., \& Dikilitas, K. (2015). EFL students' speaking anxiety: A case from tertiary level students. International Association of Research in Foreign Language Education and Applied Linguistic ELT Research Journal,4(1), 16-27.

50. Von Worde, R. (2003). Students' perspectives on foreign language anxiety. Inquiry, 8(1), 36-49.

51. Wan Zakaria, W.Z., Rajab, A., Sayuti, N. \& Hashim, N.A. (2007). Kajian tahap keresahan di kalangan pelajar Bahasa Asing terhadap mata pelajaran Bahasa Asing. Universiti Teknologi Malaysia: Pusat Pengurusan Penyelidikan.

52. Woodrow, L. (2006). Anxiety and speaking English as ASecond Language. RELC Journal, 37(3), 308-328. https://doi.org/10.1177/0033688206071315

53. Young, D. J. (1991). Creating a low-anxiety classroom environment: What does language anxiety research suggest? The Modern Language Journal,75, 426-439. https://doi.org/10.1111/j.1540-4781.1991.tb05378.x

54. Yusri, G., Nik Yusoff, N.M. R., \& Shah, M,P. (2010). Sikap pelajar terhadap pembelajaran kemahiran lisan Bahasa Arab di Universiti Teknologi MARA (UiTM). GEMA Online Journal of Language Studies, 10(3), 1533.

55. Zhang, W., \& Liu, M. (2013). Evaluating the impact of oral test anxiety and speaking strategy use on oral English performance. Journal of Asia TEFL,10(2), 115-148.

56. Zheng, Y. (2008). Anxiety and second/foreign language learning revisited. Online Submission,1(1), 1-12. 